\title{
Structuring multicriteria model for airports selection for cargo airlines exclusively
}

\author{
Estructuración de modelo multicritério para la selección \\ de aeropuertos por aerolíneas exclusivamente cargueros
}

\author{
Miguelangelo Geimba de Lima ${ }^{1 *} \quad$ Mischel Carmen Neyra Belderrain ${ }^{1}$ \\ Recibido 8 de octubre de 2014, aceptado 20 de noviembre de 2015 \\ Received: October 8, $2014 \quad$ Accepted: November 20, 2015
}

\begin{abstract}
The scenario generated by the increasing role of lead logistics providers, as well as a possible increased competition caused by government grant for some major Brazilian international airports, is demanding from those involved in the air cargo supply chain actions that promote improvements in services in order to make them more efficient. Influenced by this concern, this paper proposes a Three-Phase Method of multicriteria decision aid for the major services of the Brazilian international air cargo logistics chain. Using the foundations of the proposed method, the Phase 1 and Phase 2 are elaborated. In Phase 1, problem consolidation was performed and also the two main logistics strategic decisions were identified. In Phase 2, structuring multicriteria model is elaborated, identifying the aspects of such as criteria and sub-criteria for strategic decision of cargo only airlines, when selecting Brazilian international airports. In this Phase is also constructed, for a specific case-study, the hierarchical structure of the problem is also constructed.
\end{abstract}

Keywords: Logistics chain, airports, strategic decision, multicriteria, cognitive processes.

\section{RESUMEN}

El escenario generado por el creciente papel de los operadores logísticos, así como un posible aumento de la competencia provocada por la concesión de algunos de los principales aeropuertos internacionales brasileños, está exigiendo de los actores de la cadena logística de carga aérea iniciativas que promuevan la mejora de los servicios a fin de que hacerlos más eficientes. Influenciado por esta preocupación, este trabajo propone un método de tres fases de ayuda multicriterio a la decisión, para los principales servicios de la cadena logística de la carga aérea internacional brasileña. Usando los fundamentos del método propuesto, la Fase 1 y la Fase 2 se elaboran. En la Fase 1 se logra la consolidación del problema y también la identificación de dos grandes decisiones estratégicas logísticas. En la Fase 2 se desarrolla la estructuración del modelo multicriterio, identificando los aspectos, criterios y subcriterios para la decisión estratégica de aerolíneas exclusivamente cargueros en la selección de aeropuertos internacionales brasileños. En esta etapa también está elaborado para un estudio de caso específico, la estructura jerárquica del problema.

Palabras clave: Cadena logística, aeropuertos, decisión estratégica, multicriterio, procesos cognitivos.

1 Divisão de Engenharia Mecânica. Instituto Tecnológico de Aeronáutica. 12228-900. São José dos Campos - SP, Brazil. E-mail: mgeimba@gmail.com; carmen@ita.br

* Corresponding author 


\section{INTRODUCTION}

Air freight is an important driver of industrial and commercial development, facilitating inter-modality and fostering domestic and foreign markets. It accounts for only $2 \%$ of world cargo ton-miles, though its representation is significant as it represents $35 \%$ of monetary values [12]. Considering the amount of air cargo in Brazilian foreign trade, its contribution is relevant, as in 2012 it represented $17.63 \%$ of the country's total imports, and $4.61 \%$ of total exports, of monetary values [18]. It is ideal for shipping under the "Just in time" method of manufactured products with high added value.

Regarding decisions, the logistics chain of international Brazilian air cargo has quite a complex dynamic. This complexity arises from the number of participants and parameters for analysis, in order to make good decisions. In this analysis, the need for a systemic view in order to define and develop instruments to assist in the decision-making processes in a timely manner and at the required quality is eveident. The studies concerning the use of approaches for supporting decision-making regarding airports focuses on passenger operations, not presenting multicriteria models for supporting decision-making regarding cargo airports.

Influenced by these concerns, this paper proposes a Three-Phase Method of multicriteria decision aid for the major services of the Brazilian international air cargo logistics chain. In this study the two first Phases will be developed.

In Phase 1, problem structuring is performed: mapping of the Brazilian international air cargo logistics chain; identifying its characteristics, stakeholders, material and information flows; as well as the identification and consolidation of the problem. In this Phase is also identified the two main logistics strategic decisions are also identified. These two strategic decisions are sequential in the logistic chain, they use the same airport structure, and the choice of decision 2 directly affects decision 1 (show below).

Decision objective 1- Decision about air freight forwarders in ordering and selecting international cargo airlines, aiming towards the development of strategic partnerships; Decision objective 2 - Strategic decision of cargo only airlines in ordering and selecting Brazilian international airports, aiming to prioritize resources for the transport and maintenance of logistics bases.

In Phase 2, structuring multicriteria model is elaborated, identifying the aspects such as criteria and sub-criteria for strategic decision 2 . In this Phase, for a specific case-study, the hierarchical structure of the problem is also constructed. As a support to the Phase 1 and Phase 2, Value-Focused Brainstorming (VFB), and two decision-making groups (one for is also constructed, the Phase 1 and another more specific for Phase 2) will be used.

This work is divided in the following way: firstly, we present the literature review, secondly, we present the processes of multicriteria decision analysis; thirdly, we present the method of multicriteria decision aid; after that, we describe the conclusions.

\section{LITERATURE REVIEW}

Several studies concerning the use of approaches for supporting decision-making regarding airports were developed during the past decades. Most of them use tools such as Data Envelopment Analysis (DEA) in order to measure efficiency and also to detect benchmarks. Wanke [16] performed on the use of different approaches for assessing efficiency related-issues in 63 major Brazilian airports with the help of DEA and Free Disposal Hull (FDH). Koçak's [6] perform analyses for 40 airports in Turkey were examined with the help of DEA. Yoshida [26] considers the "endogenous-weight total factor productivity" method as a critique of DEA models, and illustrates the methodology for Japanese airports. Jardim [19] shows the efficiency evaluation of either a set of airports or the same airport along several years and under several constraints based on two multidimensional tools, DEA and MACBETH.

In studies where it is necessary to select criteria, we may consider Soares de Mello [25] who worked with a type of multicriteria method so as to evaluate the size of 9 Portuguese airports. The criteria applied refer to aircraft, passenger and cargo movement. Pinheiro \& Soares de Mello [20] presented different ways for airport ordering, according to its size, taking into account passenger, cargo and aircraft movement. Bandeira [2] applied the Analytic Hierarchy Process 
(AHP) in order to determine the importance that customers give to various components of a passenger terminal in a specific airport. M. N. Postorino \& F. G. Praticò [13] applied the multicriteria decisionmaking methods to a regional multi-airport system (MAS) so as to verify the role/position of each airport within the MAS. Gardiner [9] through a literature review identified 17 factors which determine airport selection by cargo airlines.

Despite all those efforts, great number of researches focus on passage operations, not presenting multicriteria models for supporting decision-making regarding cargo airports.

\section{THE PROCESSES OF MULTICRITERIA DECISION ANALYSIS}

According to Ensslin [8] and Belton [3] the processes of Multicriteria Decision Analysis (MCDA) is a set of activities which aims to support decision-makers in a scientific manner. Figure 1 summarizes the processes of MCDA in four Phases. In this review the two first Phases will be detailed.

\section{Phase 1 - Problem structuring}

For Hisschemoller (1993) apud Kruijf [11] problem structuring is a form of interaction between the various interested actors aiming to raise awareness and understanding of the problem of integration, exchange, evaluation, confrontation and use.

Problem Structuring Methods (PSMs) are approaches that seek to account for situations where the quantitative approach cannot be applied due to the fact that there is a need for emphasizing the qualitative and subjective aspects of decision processes [17]. The best-known PSMs are: Strategic Options
Development and Analysis (SODA), Strategic Choice Approach (SCA), Soft Systems Methodology (SSM) and Value-Focused Brainstorming (VFB). These methods facilitate the whole process of decision support (problem and multicriteria model structuring). Among the methods VFB and SODA (cognitive maps) are used and explained below.

\section{a) Value-Focused Brainstorming}

Brainstorming is a technique developed to explore the creative potential of an individual or a group by placing it in the service of predetermined goals. Keeney [14] suggests the VBF, which includes a group of four Steps for structuring problems effectively.

The four Steps of VFB are: Expressing the problem to be solved; identifying the objectives of a possible solution; generating solutions individually; after having clarity of the issues, the objectives and personal solutions to the problems, are assessed by the group. It appears that each component of the group must have clarity regarding the problem, and their perception concerning possible objectives and solutions. With this initial commitment, the decisionmaking group could consolidate the problem, and elaborating effective solutions.

b) Strategic Options Development and Analysis SODA aims to capture different views of decisionmaking groups about the problem, building individual cognitive maps and providing the structure for the group discussion (and the facilitator) in order to guide participants towards a portfolio of shared agreement [23]. The cognitive map is defined as a hierarchy of concepts related by influence connections between concepts, means and ends, and is used to structure, analyze and understand problems [21].

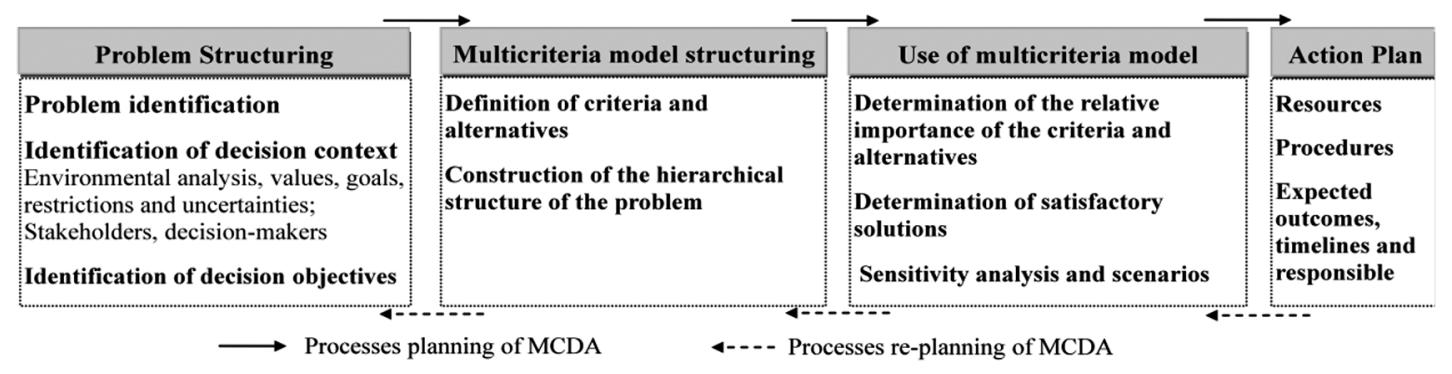

Figure 1. The processes of MCDA.

Source: Adapted from BELTON [3]. 
Structuring the problem involves problem identification, the decision context and the decision objectives which are explained below.

\section{Problem identification}

For Eden 1983 apud LIMA [15] the problem involved not only the existence of error or an undesired result. In this sense the knowledge of environment, its restrictions and uncertainties are important considerations in identifying the problem.

The decision-making groups may have very distinctive intentions when confronted with problems. According to these cited intentions, Roy [1] proposes four basic problematic formulations (dependent on each other):

a) Choice and selection of problems $(\alpha)$, which are aimed at selecting the best alternative (or a group of best choices);

b) Allocation in problem categories $(\beta)$, which are designed to categorize available choices according to similar classification elements;

c) Problem ordering $(\gamma)$ : when there is the need to establish alternative priorities;

d) Describing problems $(\delta)$, which are linked to the objective of formally describing the choices (and their main characteristics).

\section{Identification of decision context}

In order to identify the decision context, knowledge of the environment is needed, through the understanding of its constraints, stakeholders, among other things. By understanding the context it is possible to identify the decision-makers, the problem and the decision objective [3].

Knowledge of all logistic flows (stakeholders, constraints and uncertainties) is fundamentally important for the identification of the decision context in the logistics chain. As far as they are known, there is the possibility to develop instruments to assist the decision-making processes of services hiring and development of strategic partnerships.

Logistics is the process of the planning, execution, and control of the procurement, movement, and stationing of personnel, material, and other resources to achieve the objectives of a campaign, plan, project, or strategy. As companies integrate their efforts in order to offer customers more than the delivery of merchandise at the right place and time, one can speak of Supply Chain Management (SCM), defined as being the integration of business processes from end user until the original suppliers who provide products, services and information, in order to add value to the customer [4].

Both concepts prescribe the existence of multiple flows (materials, information, finance, etc.) that must be effectively managed so that the organizations can achieve competitive levels that allow them to maximize their results. Several authors have presented different approaches to the processes involving logistic flows; however, they all consider the flow of information to be bidirectional. It happens that, in the light of any product return, coupled with the fact that the Reverse Logistics is an irreversible reality; all flows are considered bidirectional (Figure 2).

\section{Identification of decision-makers}

The identification of interest groups is of great importance in the decision-making processes as the chosen alternative depends directly on information provided by the participants involved [8]. The interest group may also participate in the problem and the structuring multicriteria model.

It is possible to distinguish actors of a decision-making process as "passive actors" and "stakeholders". The passive actors are those who are affected by the consequences of actions taken, and therefore act passively in the decision-making process. Stakeholders are those actors who directly participate in the decision-making process, dividing them between decision-makers, representatives and facilitators [8].

\section{Phase 2 - Multicriteria model structuring}

The structuring multicriteria model structuring relates the identification the criteria, alternatives, the construction of the hierarchical structure, and the selection of the most appropriate multicriteria method. The main multicriteria methods are: Analytic Hierarchy Process (AHP), Analytic Network Process (ANP), Measuring Attractiveness by a Category Based Evaluation Technique (MACBETH), among others.

Among the existing methods, the AHP is one of those with the most suitable features to support decision-making regarding planning processes in transportation and logistics [22]. 


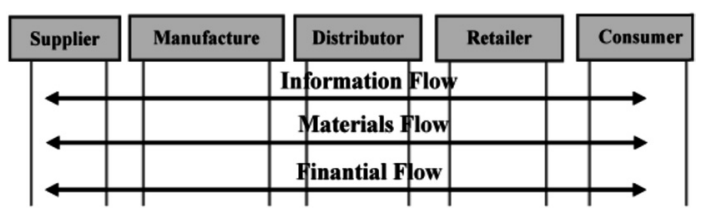

Figure 2. Logistic Flows.

Source: Corrêa [4].

\section{Definition of criteria}

The criteria are aspects considered by the decisionmaker as fundamental for evaluating potential actions and must satisfy the following properties: essential to achieving strategic objectives; controllable; complete; measurable; operational; be isolable; not being redundant; concise, and; understandable [10]. According to these properties the criteria may have characteristics of quantitative and qualitative analysis.

Dornier [7], Corrêa [5] and Slack [24] define six performance criteria that may influence customer choices (retailers, manufacturers and customers of logistics services providers); as explained below.

\section{a) Price/ cost of product and/or services}

The price of the product or of the service is a component of the cost perceived by the customer. There are also other costs such as those related to transportation, costs of any non-conformity, storage costs and maintenance of inventories caused by possible inflexibility of the supplier and / or logistics service providers, among others.

\section{b) Delivery speed}

It is the time from the moment of a client's viewing of the product to order placement to delivery of the product or service.

\section{c) Delivery reliability}

It refers to the ability of the supplier or provider of logistics services to meet their delivery promises in terms of time and quantities.

\section{d) Delivery flexibility}

It is a performance criterion that represents the greater or lesser capacity of the supplier or provider of logistical services to change what you do. Change can have two distinct aspects: it can mean changing very quickly or it could mean changing what you do.

\section{e) Quality of products and/or services}

It is a performance criterion with regard to providing defect-free products, in accordance with specifications.

\section{f) Services provided to the customer}

It relates to those components which are not tangible or are not physical goods offered to customers. In logistics and transportation services we can talk about vendor management inventory.

Analyzing from the perspective of the customers, it is possible to say that for the company to be competitive, it must be able of outperform competition in the performance criteria that the targeted niche markets value more, for this it must monitor the market through the main sub-criteria valued by the customers, understanding their needs, and later through its strategic positioning, organizing its internal and logistic aspects.

\section{METHOD OF MULTICRITERIA DECISION AID}

The method of multicriteria decision aid for the major services of the Brazilian international air cargo logistics chain is presented in Figure 3 by a sequence of three Phases. In this study the two first two Phases will be developed.

\section{Phase 1 - Problem Structuring}

In order to support problem structuring, Steps 1, 2 and 4 of VFB were used. The VFB reinforced the commitment of each component in identifying and consolidating the problem, the decision context and objectives individually. With this initial commitment, the decision-making group could identify and consolidate the problem and also define the main logistics strategic decisions. These processes were developed in four rounds of re-planning.

\section{Step 1 - Problem structuring identification of the decision-making group}

In order to define the decision-making group for the problem structuring, visits to airports, unions and associations representing the sector were made. Obtaining the participation of employees (logistics operations managers) from twelve air freight forwarders and six exclusively cargo airlines. 


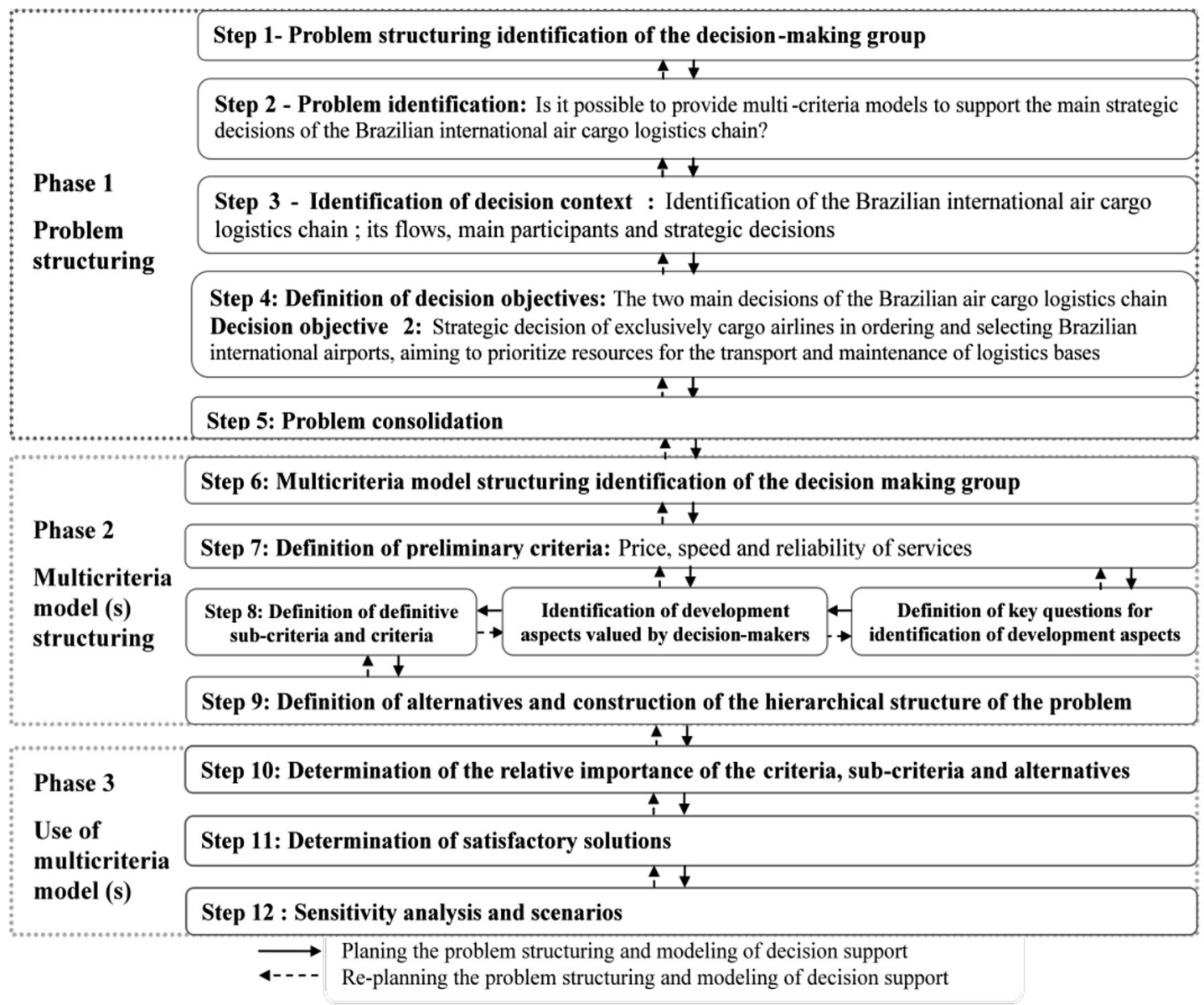

Figure 3. Phases of the method of multicriteria decision aid.

\section{Step 2 - Problem Identification}

The scenario generated by government concessions of some major Brazilian international airports, as well as the increasing role of lead logistics providers, is demanding for the participants of the air cargo supply chain, actions for obtaining a competitive advantage. Considering the aspect above (and the literature review did not present multicriteria models for supporting decision-making regarding cargo airports), there is a need to elaborate multicriteria models to subsidize logistics and transportation managers, seeking solutions that promote improving the efficiency of services. With the development of these models, the following question hopefully can be answered: Is it possible to provide multicriteria models to serve as a reference for strategic decisions, which involve the development of partnerships and contracting services for the main stages of the logistics chain of Brazilian international air cargo?
Step 3 - Identification of the decision context Regarding identification of the decision context, and the main strategic decisions, Figure 4 shows the simplified model of processes involving the logistic flows of Brazilian international air cargo. In order to define the approach to be used, the responsibility of shipping as being of air freight forwarders in front of the producer or manufacturer is considered, as well as the choice of high-value cargo as product. This cargo includes electronic and mechanical components for automotive and computer, among others.

In Figure 4 it is possible to see the main participants, the direction of participants influence on the performance, flow of materials, the theoretical flow of information and the actual hiring flows (partial information) between each step of the logistics chain. 


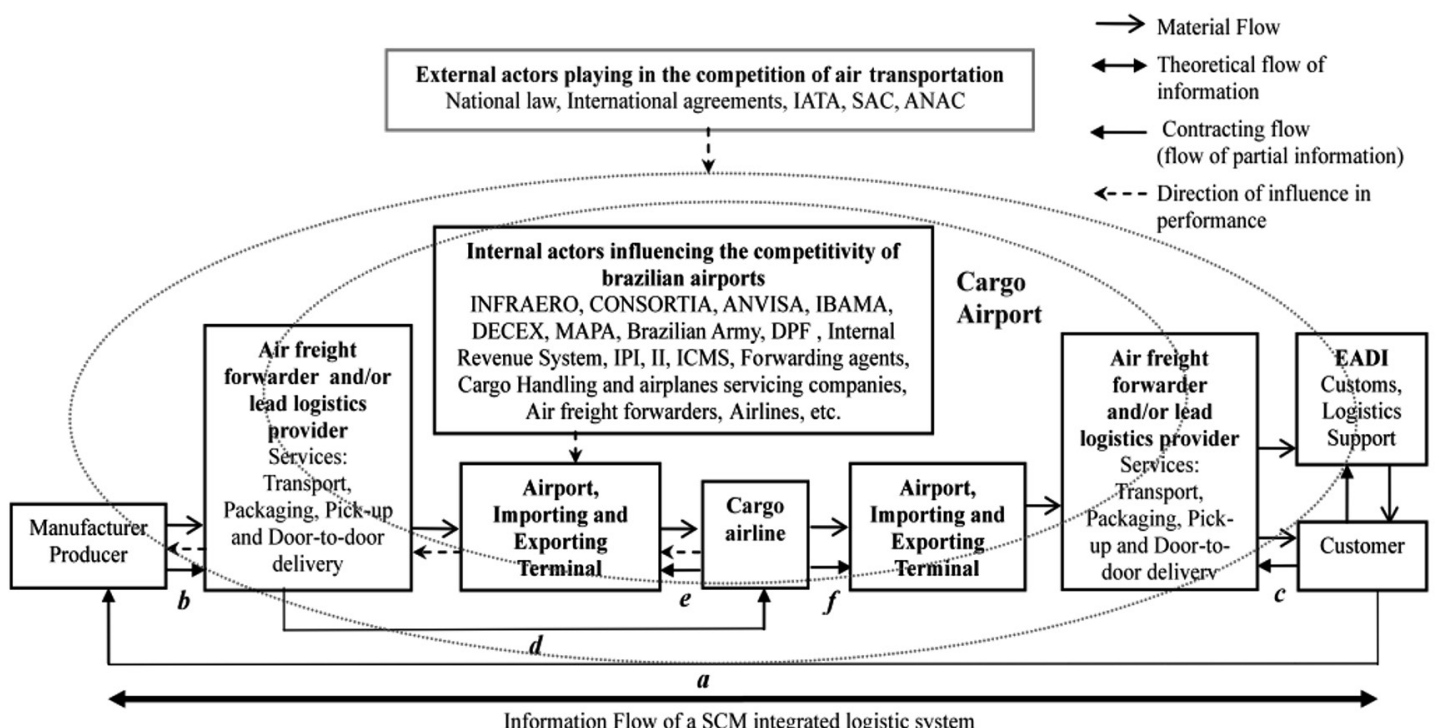

Figure 4. Material and information flows of the logistics chain of Brazilian international air freight considering the air freight forwarder as a lead logistics provider.

Besides the producers, customers (retailers, manufacturers, etc.), air freight forwarders, airports and airlines, there are players that influence the competitiveness of air freight. We can quote: IATA (International Air Transport Association), SAC (Secretaria de Aviação Civil), ANAC (Agência Nacional de Aviação Civil), among others.

Noting that there is little integration between participants, and that the inefficiency of one actor's performance entails the inefficiency of the whole supply chain, SCM is far from being reached.

The service hiring flows (partial information flows) typically proceed as follows: the customer buys a product from a company (flow a); the transport contract for the customer can be accomplished in two ways: i) the producer hires an air freight forwarder or a lead logistics provider to perform the management of its cargo until the final destination (flow b), or ii) the hiring is undertaken by the customer (flow c); the air freight forwarder hires an cargo airline to transport (flow d); the cargo airline uses airports to collect (flow e), and also for product delivery (flow f). This hiring flow becomes an information flow, when there is feedback to the customer in the form of management and strategic information.

The flows of materials proceed as follows: the product coming from the manufacturer follows, mainly, overland by an air freight forwarder or by a lead logistics provider to the airport of origin. In the airport this load is consolidated, unitized and shipped on an cargo airlines that carries it to the destination airport. The is transfer to the destination airport may occur by connections and transshipment of cargo at other airports until it arrives at its destination.

There is still the scenario in which the possibility of the cargo airline performing the services of lead logistics provider, as shown in Figure 5.

\section{Step 4 - Definition of decision objectives}

The two main strategic decisions (DO1 and DO2) related to the supply chain, concerning the Brazilian international air cargo, were defined by a decisionmaking group. This is the case because they represent the largest share of costs, transportation, storage, fractioning and communication. These two strategic decisions use the same airport structure, are sequential in the logistic chain and the choice of decision 2 directly affects decision 1 . In this study the Phase 2 (multicriteria model structuring) of the method will be developed for the purpose of decision 2 .

Decision Objective 1 (DO1) - Decision about air freight forwarders in ordering and selecting international cargo airlines, aiming towards the development of strategic partnerships (Flow d, Figures 4 and 5); 


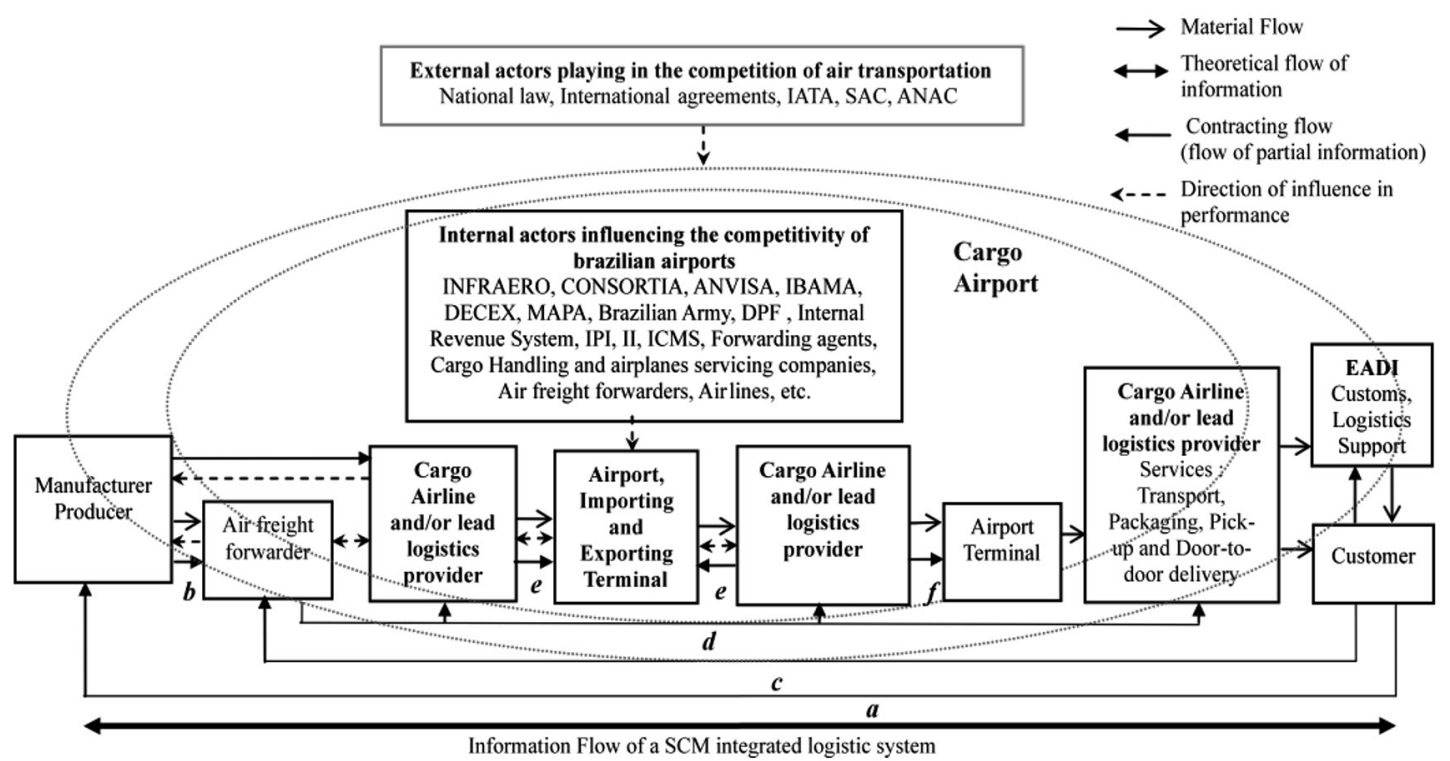

Figure 5. Material and information flows of the logistics chain of Brazilian international air freight considering the cargo airlines as a lead logistics provider.

Decision Objective 2 (DO2) - Strategic decision of exclusively cargo airlines in ordering and selecting Brazilian international airports, aiming to prioritize resources for the transport and maintenance of logistics bases (in them or in neighboring regions) (Flow e, Figures 4 and 5).

\section{Step 5 - Problem consolidation}

The redefined problem for decision objective 2 is: Is it possible to provide a multicriteria model for the strategic decision of cargo only airlines in ordering and selecting Brazilian international airports (aiming to prioritize resources for the transport and maintenance of logistics bases)?

In relation to the referenced problem, this may be seen as an example of ordering and selecting of possible alternatives.

\section{Phase 2 - Multicriteria model structuring}

In order to support the structuring multicriteria model, Steps 3 and 4 of VFB were used. These Steps were used in the elaboration of the cognitive processes for defining: aspects, sub-criteria and definitive criteria through preliminary criteria valued by exclusively cargo airlines. The VFB reinforced the commitment of each component (of the decision-making group) in the elaboration of the cognitive processes. With this initial commitment, the decision-making group could consolidate these processes. These processes were developed in four rounds of re-planning.

\section{Step 6 - Structuring Multicriteria model structuring identification of the decision-making group}

The decision-making group for the structuring multicriteria model was divided for both decisions; one for decision 1 (composed of logistics operations managers from twelve air freight forwarders), and the other decision 2 (composed of logistics operations manager from six companies; including three Brazilian and three non-Brazilian cargo only airlines).

\section{Step 7 - Definition of preliminary criteria}

The criteria and sub-criteria were identified by cognitive processes developed through the definition of preliminary criteria, aspects of development valued for the respective preliminary criteria, subcriteria and definitive criteria. This identification was accomplished through qualitative interviews with decision-makers from an adaptation of the works of Dornier [7], Slack [24] and Corrêa [5]. These works define six performance criteria that may influence customers (retailers, manufacturers and customers of logistics services providers) choice: price of product and/or services, delivery speed, delivery reliability, delivery flexibility, quality of 
products and/or services and services provided to the customer.

If these concepts are approached from the point of view of cargo only airlines point of view, it is possible to say that to make good strategic decisions under a logistics perspective, the decision-makers must set the primary selection criteria. With these criteria it will be possible to verify through an analysis of its logistics services providers the most valued performance aspects in hiring and developing strategic partnerships for its service. Through cognitive processes with the aspects, one arrives at the respective sub-criteria and definitive criteria, as shown in Figure 6 and detailed in Step 6 of the method.

The members of the decision-making group, by the properties of not being redundant, being essential, controllable, complete, measurable, operational, isolable, concise and understandable for achieving strategic objectives, initially defined the criteria to include price, reliability and the speed of service.

The use of the description price rather than cost was due to the fact that all criteria affect (positively or negatively) the value perceived by the customer. The exclusion of the quality criteria was due to its characteristics linked to projects and product compliance. Exclusion can also be justified if the criterion was changed to quality of service. In this case it would be part of the criteria of speed, reliability and flexibility. The same explanation can be used to assess the service provided to the customer. The union of criterion flexibility to criterion of speed was due to the fact that flexibility criterion in logistic services and transportation has a connotation of changing quickly, which justifies the fusion.

\section{Step 8 - Definition of sub-criteria and definitive criteria}

Through qualitative interviews conducted with key questions concerning primary criteria, performance aspects valued by decision-making groups of exclusively cargo airlines were identified. Through cognitive processes the following definitive criteria and sub-criteria were established. These cognitive processes will be presented in the following Steps (shown below).

Key Questions: Concerning the prioritization of resources for transport and maintenance of logistics bases in Brazilian international airports (or surrounding areas), we ask: which performance aspects (related to price, speed and reliability of services) provided by airports positively influence the competitiveness of your company as cargo only airline?

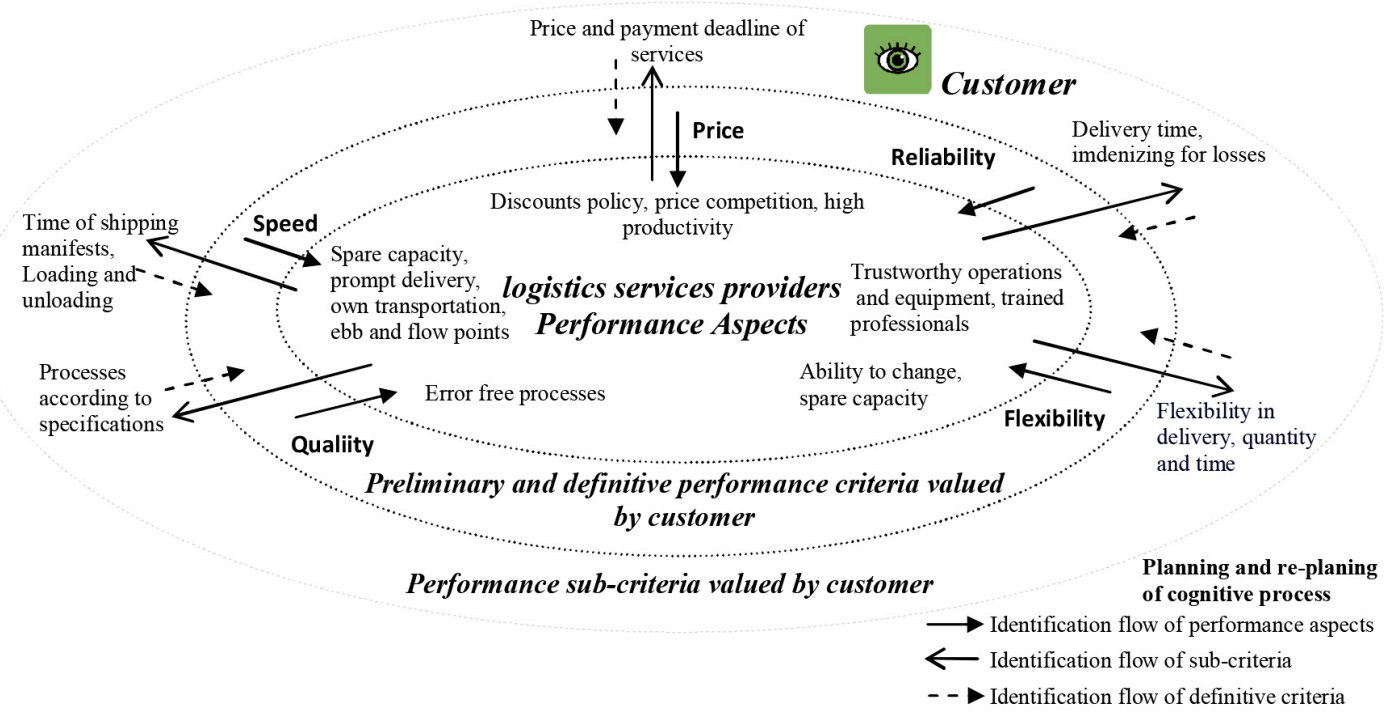

Figure 6. Defining cognitive processes of preliminary criteria, aspects, sub-criteria and definitive criteria Source: Adapted from Dornier [7], Corrêa [5] and Slack [24]. 
Step 8.1 - Identification of performance aspects under the view of cargo airlines exclusively

The responses from the qualitative interviews showed a need to consolidate the number and quality of selected aspects. In this sense a review of these aspects considering quantitative variables was made by means of a ratio scale. The scores of this scale are (including intermediate values): 1 (not important), 2 (relatively important), 3 (important) 4 (very important) to 5 (extremely important). This review had 30 aspects that were evaluated by decision-makers. The results of the evaluation under the view of cargo airlines are shown in Table 1.

Table 1. Evaluation of performance aspects under the view of exclusively cargo airlines.

\begin{tabular}{|c|c|c|c|}
\hline $\mathbf{N}^{0}$ & $\begin{array}{c}\text { Evaluation statement of performance aspects under } \\
\text { the view of exclusively cargo airlines }\end{array}$ & Criteria & $\begin{array}{c}\text { Mean } \\
(\mathrm{N}=6)\end{array}$ \\
\hline 1 & $\begin{array}{l}\text { Proximity of the airport with the demand generator center (big urban centers, centers } \\
\text { of supply and demand of cargo such as other airports and ports) }\end{array}$ & $\mathrm{S}$ & 4.854 \\
\hline 2 & Convenient slots (available time in desired periods) & $\mathrm{S}$ & 4.821 \\
\hline 3 & Fees for the use of airport spaces & $\mathrm{P}$ & 4.750 \\
\hline 4 & Aircraft operating fees & $\mathrm{P}$ & 4.750 \\
\hline 5 & Discounts policy (aero) & $\mathrm{P}$ & 4.731 \\
\hline 6 & High demand for air cargo service & $\mathrm{S}$ & 4.666 \\
\hline 7 & $\begin{array}{l}\text { Structures of airstrips, takeoff and taxi (airport structure for landings and simultaneous } \\
\text { takeoffs, taxiways with easy access to the patios of cargo terminals, aircrafts or remote areas) }\end{array}$ & $\mathrm{S}, \mathrm{R}$ & 4.632 \\
\hline 8 & Deadlines for fees payments & $\mathrm{P}$ & 4.625 \\
\hline 9 & $\begin{array}{l}\text { Terrestrial access systems, circulation and parking area for trucks loading and } \\
\text { unloading at the airport }\end{array}$ & $\mathrm{S}, \mathrm{R}$ & 4.542 \\
\hline 10 & $\begin{array}{l}\text { Patio structure for aircraft servicing on ground (structure of the airports in relation to patios } \\
\text { of cargo terminals, aircrafts or remote area terminals and subcontractors supporting aircrafts) }\end{array}$ & $\mathrm{S}, \mathrm{R}$ & 4.378 \\
\hline 11 & $\begin{array}{l}\text { Agile processes regarding customs (airport consenters, customs brokers and other actors } \\
\text { with the necessary structure) }\end{array}$ & $\mathrm{S}$ & 4.354 \\
\hline 12 & $\begin{array}{l}\text { Structure of the air traffic control (capacity and efficiency of navigation in the approaching } \\
\text { area and aerodrome control) }\end{array}$ & $\mathrm{S}, \mathrm{R}$ & 4.321 \\
\hline 13 & Management of losses and damages & $\mathrm{R}$ & 4.292 \\
\hline 14 & $\begin{array}{l}\text { Structure of patios for cargo transfer between aircrafts and cargo terminals (structure } \\
\text { of the airport in relation to patios of cargo, aircrafts or remote area and outsourced } \\
\text { companies of loading and unloading cargo on planes, among others) }\end{array}$ & $\mathrm{S}, \mathrm{R}$ & 4.146 \\
\hline 15 & Conscious management in policies for price increasing & $\mathrm{P}$ & 4.083 \\
\hline 16 & Trained professionals (handling, organization and others) & $\mathrm{S}, \mathrm{R}$ & 4.063 \\
\hline 17 & Night operations & $\mathrm{P}, \mathrm{S}$ & 4.053 \\
\hline 18 & Management of airport capacities to meet the demand & $\mathrm{P}, \mathrm{S}, \mathrm{R}$ & 4.042 \\
\hline 19 & Price competition & $\mathrm{P}$ & 3.875 \\
\hline 20 & Operational planning in group regarding the offered services & $\mathrm{P}, \mathrm{S}, \mathrm{R}$ & 3.729 \\
\hline 21 & $\begin{array}{l}\text { Structure of the cargo terminal for handling, storage, wharfage and cargo transfer } \\
\text { between modals }\end{array}$ & $\mathrm{S}, \mathrm{R}$ & 3.688 \\
\hline 22 & Taxes and subsidies applied by the locality in which the airport is inserted & $\mathrm{P}$ & 3.666 \\
\hline 23 & Reliability of landings & $\mathrm{R}$ & 3.500 \\
\hline 24 & Airport weather conditions & $\mathrm{R}$ & 3.455 \\
\hline 25 & Strategic integration between airport and airline & $\mathrm{P}, \mathrm{S}, \mathrm{R}$ & 3.354 \\
\hline 26 & Systems that ease the information flow & $\mathrm{S}, \mathrm{R}$ & 3.292 \\
\hline 27 & Planning of airport expansion & $\mathrm{P}, \mathrm{S}, \mathrm{R}$ & 3.095 \\
\hline 28 & Airport with structure and experience in national and international cargo transportation & $\mathrm{V}$ & 3.000 \\
\hline 29 & Airport environmental policy & $\mathrm{P}, \mathrm{S}, \mathrm{R}$ & 2.963 \\
\hline 30 & Periodic maintenance of infrastructure & $\mathrm{R}$ & 2.875 \\
\hline
\end{tabular}

$\mathrm{R}$ - Reliability of services criteria S - Speed of services criteria P - Prices of services criteria. 
They show that the most important aspect to be considered by administrators and airport planners is the proximity of the airport in relation to the demand generator.

An explanation for the valuation of the aspect in question is found in the operational costs for collection and shipment of cargo to an airport distant from the producer or consumer center. This factor relates as demand generating center, huge urban centers, centers of supply and demand of cargo such as other airports and ports.

The second most important aspect to be considered is the convenient slots. An airport slot is a right granted by an airport owner which allows the slot holder to schedule a landing or departure during a specific time.

The interesting results shown are related to the aspects that are among the $3^{\text {rd }}$ and $5^{\text {th }}$ places, represented by the fees of aircraft operations, fees of airport space usage and discount policy of aeronautics fees. Such variables represent the hegemony of the price of services as being the most important criterion in the analysis and choice of cargo airports.

Other interesting results shown are related to aspects which are in the $7^{\text {th }}, 9^{\text {th }}, 10^{\text {th }}, 11^{\text {th }}, 14^{\text {th }}$ and $21^{\text {st }}$ places, represented by the terrestrial access systems, processes regarding customs speed, structure of the cargo terminal, and structure of the patios for cargo transfer and aircraft servicing on ground. Such aspects represent the importance of airport structure organization.

It becomes incomprehensible, under the point of view of decision-makers, the excess of investments of national airport management at certain airports, which do not have urgent needs for improvements due to demand or capacity matters.

\section{Step 8.2 - Sub-criteria and definitive criteria definition through performance aspects}

From the aspects previously presented and inspired by the Analytic Hierarchy Process (AHP), and the individual and aggregated cognitive mapping (of the decision-making group), the processes of sub-criteria and definitive criteria definition were elaborated.
By using an action verb for each aspect and questions such as "why is this aspect important to achieve the best price, speed and reliability of services?" This process continues towards the goal (sub-criteria and definitive criteria definition) of the decisionmaking group. With this procedure the criteria were confirmed and 10 sub-criteria were obtained. Each sub-criterion is complemented by strategic and structural aspects, capacity and management techniques of the cargo airports.

Figure 7 and Figure 8 the criteria, sub-criteria and support aspects to decision support for the strategic choice are shown. If the decision is operational then the number of sub-criteria may vary, and in some cases, aspects can become sub-criteria. This flexibility of the cognitive processes from aspects to criteria is of great value in any decision analysis concerning the choice of cargo airports. The criteria and their respective sub-criteria (for the strategic choice) have characteristics of qualitative analysis and are listed below:

\section{Criterion speed of services}

The criterion speed of services comprises sub-criteria (relating to choice of airports), that streamline logistic services (transport, packaging, pick-up, door-to-door delivery, among others), offered by exclusively cargo airlines as well as by their customers (air freight forwarders, lead logistics providers, manufactures, etc.).

\section{Sub-criteria:}

Service time of air transportation from the airport for intended origins and destinations (travel time, its connections and transshipments for intended origins and destinations and approach time caused by air traffic control);

Runway and patio times to service the aircraft (airport structure for simultaneous landing and takeoffs, taxiways with easy access to the aircrafts, cargo terminals or remote area patios; structure of the airport regarding the cargo terminal patio, aircrafts or remote areas and aircraft service companies);

Service time of the patios regarding cargo transfer between aircrafts and aircrafts and cargo terminals (airport structure regarding the cargo terminal patio, aircrafts or remote area and companies of cargo handling and moving); 


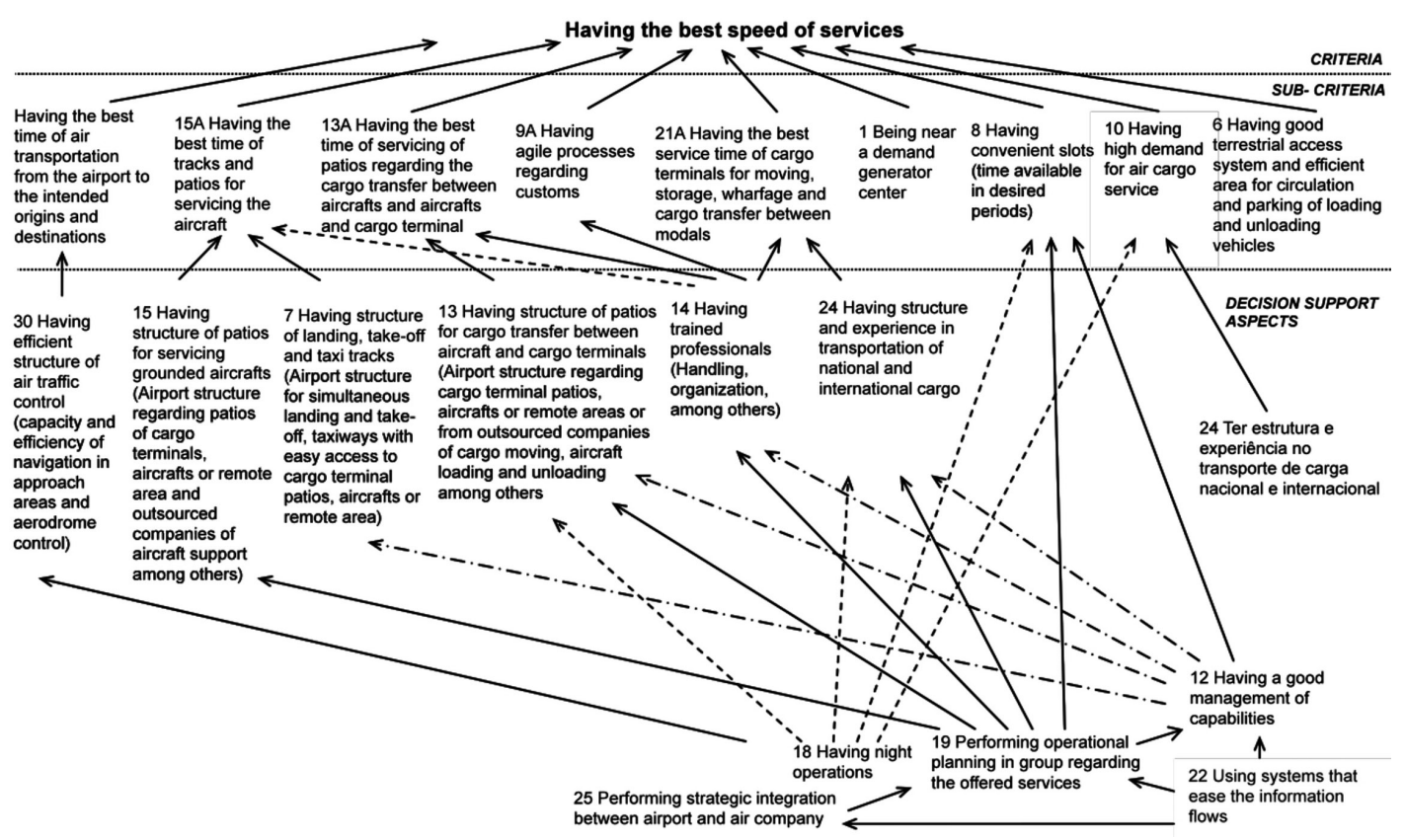

Figure 7. Identification of speed criteria and respective sub-criteria and aspects.

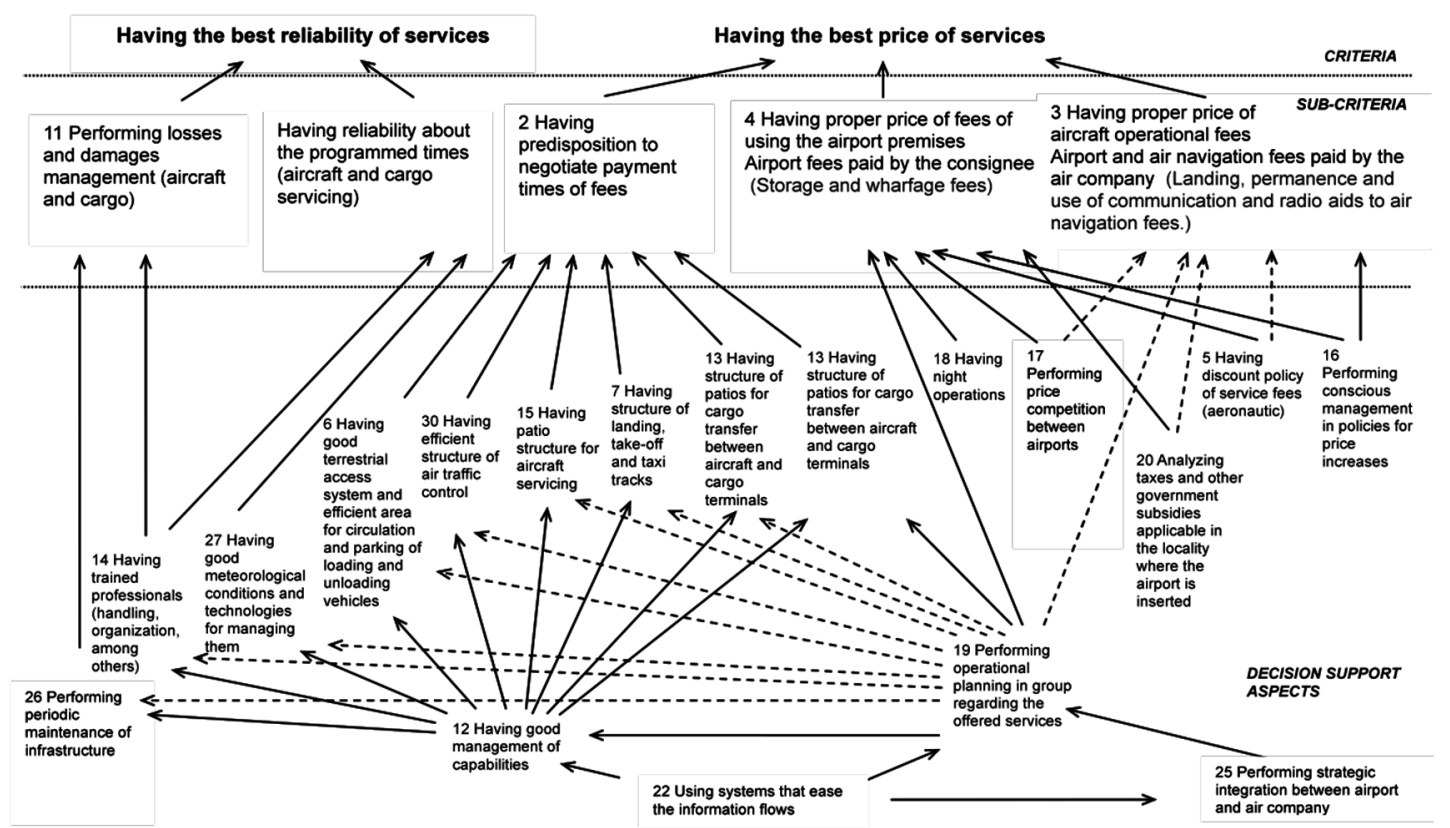

Figure 8. Identification of price and reliability criteria and respective sub-criteria and aspects.

Service time of cargo terminals regarding; handling, storage, wharfage and cargo transfer between modals;

Earth system of airport access, circulation and parking area for loading and unloading vehicles; Convenient slots - available time in desired periods;
Service time of customs processes - having the necessary structure and agile process of consenters, customs brokers and other actors from the airport;

Proximity to the demand generator center - being close to major urban centers, centers of supply 
and demand of cargo such as other airports and ports;

High demand for service air cargo - cargo density of the airport for shipping and return.

\section{Criterion price of services}

The criterion price of services comprises sub-criteria (relating to choice of airports), that addresses prices and payment terms of tariffs.

\section{Sub-criteria:}

Fares for using the airport premises - Airport Airport Rates paid by the cargo consignee (storage and wharfage charges);

Fares for the aircraft operation - airport and air navigation tariffs, paid by the airline

Payment terms of tariffs.

\section{Criterion reliability of services}

The criterion reliability of services comprises subcriteria (relating to choice of airports), that addresses reliability in programmed times and minimized losses and damages.

Sub-criteria:

Reliability in programmed times (reliability in servicing the aircraft and cargo);

Minimized losses and damages (aircraft and cargo).

Step 9 - Construction of the hierarchical structure The airports SBGRU (40.85\%), SBCP (33.23\%) and SBGL $(7.05 \%)$ were selected as alternatives. These airports were chosen by the proximity (located in the Brazilian Southeast) and representativeness of $81.13 \%$ of the export and import cargo moved by Brazilian international airports [27].

After defining criteria, sub-criteria, and alternatives, the hierarchical structure of the decision model for using the AHP has been elaborated in Figure 9. In this decision model it is possible to verify the exclusion of sub-criteria "time of air transportation" of the airport to the desired origins and destinations. This exclusion is due to the fact that there is a small difference in travel time between overseas airports and the evaluated airports.

\section{CONCLUSIONS}

This paper presented a Three-Phase Method of multicriteria decision aid for the major services of the Brazilian international air cargo logistics chain.

In Phase 1 (problem structuring), a mapping of the Brazilian international air cargo logistics chain was performed in order to consolidate the problem and to identify the two main logistics strategic decisions. The understanding of the two main strategic decisions considered above (which are sequential in the logistics chain, use the same airport structure, and the choice of decision 2 directly affects decision 1 ) was determinant to the development of this paper.

In this study the Phase 2 (Structuring multicriteria model) of the method was developed for strategic decision of exclusively cargo airlines in ordering and

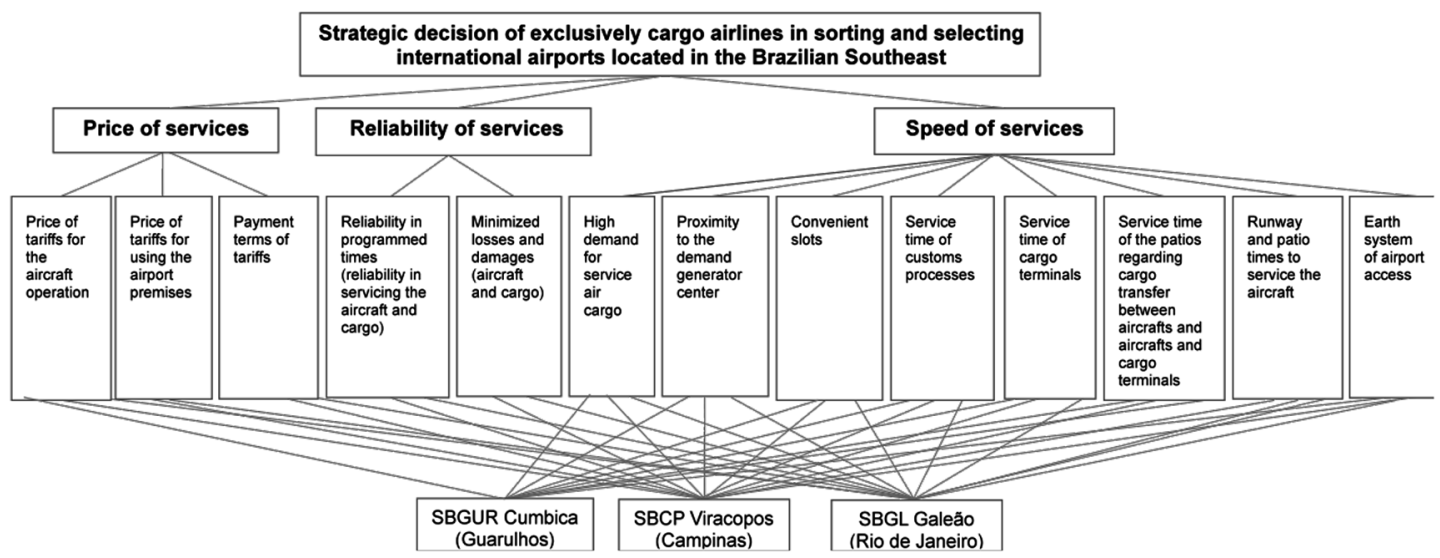

Figure 9. Hierarchical structure for strategic decision of Brazilian exclusively cargo airlines in ordering and selecting international airports located in the Brazilian Southeast. 
selecting Brazilian international airports (aiming to prioritize resources for the transport and maintenance of logistics bases). In this Phase is constructed, for a specific case-study, the hierarchical structure of the problem is constructed for a specific case-study.

As a support to Phase 1 and Phase 2, VFB, and two decision-making groups (one for the Phase 1 and another more specific for Phase 2) were used. The processes were developed in four rounds of re-planning.

In terms of contributions to the field, this study presented contributions in the elaboration of cognitive processes of preliminary criteria, aspects, sub-criteria and definitive criteria definition. The construction of cognitive processes and the hierarchical structure of the problem had a strategic connotation; if the method was addressed for an operational decision, the number of sub-criteria may vary, and in some cases, aspects can become sub-criteria deserving special attention in evaluation. This observation demonstrates the flexibility of the method, being of great value to any analysis of logistics decision.

Given the assumptions to which this study submitted, for Phase 3 (utilization of the multicriteria model) is suggested the use of the hierarchical structure proposed in conjunction with the AHP.

Considering another recommendation, one can specify the method for others logistics strategic decisions (individual or in sequence), involving services hiring and development of strategic partnerships. Sequential application is indicated because the decision-making logistics, even though individual decisions depends on several others decision makers that interfere sequentially in the logistics chains.

\section{REFERENCES}

[1] B. Roy, "Multicriteria methodology for decision aiding". Kluwer Academic Plublishers. $1^{\text {a }}$ ed. London, UK. p. 295. 1996. ISBN: 0-7923-4166-X.

[2] M.B. Bandeira, A. Correia, C. Wirasinghe. "Degree of Importance of Airport Passenger Terminal Components and Their Attributes". Aerlines Magazine, Vol. 14 Issue 37, pp. 1-4. 2007. ISSN: 0896-6575.
[3] V. Belton and T. Stewart. "Multiple Criteria Decision Analysis: An Integrated Approach". Kluwer Academic Publishers. First edition, pp. 256. Massachusetts, USA. 2002. ISBN: 0-7923-7505-X.

[4] H.L. Corrêa. "Administração de cadeias de suprimento e logística: O essencial". Atlas. $1^{a}$ ed., pp. 264. São Paulo, Brazil. 2014. ISBN: 9788522485819.

[5] H.L. Corrêa, I.G.N. Gianesi, M. Caon. "Planejamento, Programação e Controle da Produção: MRP II/ERP”. Atlas. 5a ed., pp. 452. São Paulo, Brazil. 2007. ISBN: 85-224-258-4.

[6] H. Koçak. "Efficiency Examination of Turkish Airports with DEA Approach". International Business Research, Istanbul, turkey. Vol. 4, Issue 2. 2011. ISSN: 19139004. DOI:10.5539/ibr.v4n2p204

[7] P.P. Dornier, R. Ernst, M. Fender, P. Kouvelis. "Logística e operações globais". Atlas. $1^{a}$ ed., pp. 721. São Paulo, Brazil. 2000. ISBN:85-224-258-4.

[8] L. Ensslin, G. Montibeller Neto. S.M. Noronha. "Apoio à decisão: metodologias para estruturação de problemas e avaliação multicritério de alternativas". Insular. $1^{\mathrm{a}}$ ed., pp. 295. Florianópolis, Brazil. 2001. ISBN: 85-7474-093-4.

[9] J. Gardiner. "An international study of the airport choice factors for non-integrated cargo airlines". PhD Thesis, Loughborough University. Loughborough, UK. 2007.

[10] L.F.A.M. Gomes. "Teoria da Decisão". Thomson Learning, pp. 216. São Paulo, Brazil. 2007. ISBN: 85-2210-529-4.

[11] J. De Kruijf. "Problem structuring in interactive decision-making processes: How interaction, problem perceptions and knowledge contribute to a joint formulation of a problem and solutions", pp. 134. June 2007. Access: March, 05 2014. URL: http:// www.utwente.nl/ctw/wem/organisatie/ medewerkers/vinke/thesis.pdf

[12] IATA. "Air Cargo". January 2013. Access: November, 05 2013. URL: http://www.iata. org/whatwedo/cargo/Pages/index.aspx.

[13] M.N. Postorino and F. G. Praticó. "An application of the Multi-Criteria DecisionMaking analysis to a regional multi-airport system". Research in Transportation 
Business \& Management. Vol. 4, pp. 44-52, 2012. ISSN: 2210-5395. DOI: 10.1016/j. rtbm.2012.06.015.

[14] R.L. Keeney. "Value-Focused Brainstorming". Decision Analysis. Vol. 9, Issue 4, pp. 303313. 2012. ISSN: $1545-8490$. DOI: $10.1287 /$ deca.1120.0251.

[15] A.S. Lima. "Proposta de método para modelagem de critérios de priorização de projetos de pesquisa e desenvolvimento aeroespaciais". Master dissertation, Instituto Tecnológico de Aeronáutica. São José dos Campos, Brazil. 2008.

[16] P.F. Wanke, P.F. "Efficiency of Brazil's" airports: Evidences from bootstrapped DEA and FDH estimates. Journal of Air Transport Management. Vol. 23, Issue 9, pp. 47-53. Rio de Janeiro, Brazil. 2012. ISSN: 0969-6997. DOI:10.1016/j.jairtram an.2012.01.014.

[17] L. Franco, M. Cushman and J. Rosenhead. "Project review and learning in the construction industry: Embedding a problem structuring method within a partnership context". European of Journal of Operational Research. Vol. 152, Issue 3, pp. 586-601. 2004. ISSN: 0377-2217. DOI:10.1016/ S0377-2217(03)00059-6.

[18] Aliceweb2. Ministério do Desenvolvimento Indústria e Comércio Exterior (MDIC): "Sistema de análise das Informações de Comércio Exterior Via Internet”. December 2012. Access: January 20, 2013. URL: http:// aliceweb2.mdic.gov.br//index/home

[19] J.P.F. Jardim. "Airports Efficiency Evaluation Based on MCDA and DEA Multidimensional Tools". Master dissertation. Universidade da Beira Interior. Covilhã, Portugal. 2012.

[20] M.C. Pinheiro, J.C.C.B. Soares de Mello. "Ordenação dos aeroportos do Brasil através do apoio de análises multicritério". SBPO. Gramado, Brazil. May, 2005.

[21] G. Montibeller Neto. "Mapas Cognitivos: Uma Ferramenta de Apoio à Estruturação de Problemas". Master dissertation. Universidade Federal de Santa Catarina. Florianópolis, Brazil. 1996.

[22] J.C. Caixeta-Filho e R.S. Martins. "Gestão Logística do Transporte de Cargas". Atlas. ${ }^{\text {a }}$ ed., p. 211. São Paulo, Brazil. 2001. ISBN: 97-885-224-3041-3.

[23] J. Rosenhead. "Rational analysis for a problematic world: problem structuring methods for complexity, uncertainty and conflict". Wiley. $2^{a}$ ed., pp. 386. London, UK. ISBN: 0-471-49523-9.

[24] N. Slack. "Vantagem competitiva em manufatura: atingindo competititvidade nas operações industriais". Atlas. $2^{\mathrm{a}}$ ed., pp. 218. São Paulo, Brazil. 2002. ISBN: 85-224-3260-0.

[25] J.C. Soares de Mello, E.G. Gomes, L.F.A. Gomes, L.B. Neto e L.A. Meza. "Avaliação do tamanho de aeroportos portugueses com relações multicritério de superação". Pesquisa Operacional. Vol. 25, Issue 3, pp. 313-330. 2005. ISSN: 0101-7438. DOI: 10.1590/S0101-74382005000300002.

[26] Y. Yoshida. "Endogenous-weight TFP measurement: methodology and its application to Japanese-airport benchmarking". Transportation Research Part E. Vol. 40, Issue 2, pp. 151-182. 2004. ISSN: 1366-5545. DOI: $10.1016 / \mathrm{S} 1366-$ 5545 (03)00032-2.

[27] INFRAERO. "Anuário Estatístico Operacional 2013". Access: September 5, 2013. URL: http://www.infraero.gov.br /index.php/ estatistica-dos-aeroportos.html 